\title{
Exposure to mixtures of solvents among paint workers and biochemical alterations of liver function
}

\author{
Jong-Dar Chen, Jung-Der Wang, Jenn-Pyng Jang, Yann-Yuh Chen
}

\section{Abstract}

The objective of this study was to determine biochemical alterations of liver function among paint manufacturers and sprayers associated with exposure to organic solvents. Two paint manufacturing factories and 22 various kinds of spray painting factories (16 car painting, two aircraft painting, three video terminal painting; and one trailer painting) were included. Air concentrations of organic solvents were collected by personal samplers and analysed by gas chromatography. A total of 180 workers were given a comprehensive physical examination, a questionnaire, a liver function test, and a test for hepatitis $B$ surface antigen. The questionnaire contained questions regarding detailed personal medical history, intake of alcohol, and use of medicine. Mixtures of solvents were used throughout the factories, and xylene and toluene were the major components found in almost all air samples with average contents of $46 \%$ and $29 \%$ on a weight basis of 67 air samples. No strong hepatotoxic solvents were detected. Workers were classified according to the different exposure patterns and different air concentrations of breathing zones as: high (eight hour time weighted average ( $8 \mathrm{~h}$ TWA) hygienic effects of solvents $0 \cdot 25-9 \cdot 83$, median $1 \cdot 66$ ), short term high ( $8 \mathrm{~h}$ TWA hygienic effects of solvents $0-3.38$, median 0.12), and low ( $8 \mathrm{~h}$ TWA hygienic effects of solvents all below $0 \cdot 38$ ). After applying a multivariate model to control the non-occupational factors (alcohol, medication, age, and hepatitis $B$ viral infection), increase in $\gamma$-glutamyl transferase (GGT) activity was found to be associated with severity of exposure to the mixture of solvents.

Center for the Research of Environmental and Occupational Disease, Graduate Institute of Public Health and Department of Internal Medicine, National Taiwan University, College of Medicine J-D Wang, J-P Jong, Y-Y Chen

Department of Family medicine, Provincial TaoYuan General Hospital, Taiwan, Republic of China J-D Chen
Because the possible effects on GGT activity of non-occupational factors were controlled for, it is concluded that increased GGT activity among exposed workers may be due to a higher exposure to the mixture of solvents.

Organic solvents are widely used in various industries such as paint manufacturing, spray painting, and shoemaking. Hepatotoxic effects of some of these solvents, for example, carbon tetrachloride and chloroform, were early recognised. Because some solvents produce a chronic hazardous health effect, however, it usually takes decades to document such a problem. For example, vinyl chloride was once thought to be safe and had been used for 42 years until it was found to cause liver angiosarcoma. ${ }^{12} \mathrm{An}$ occupational physician has to maintain vigilance on exposure in the workplace even though the exposure might be thought to be safe for a certain period. ${ }^{1}$ In the meantime, more epidemiological studies of these agents in the environmental situation should be performed to help the policy makers to formulate levels of exposure that do not have detrimental effects on health.

Today, with the increasing consumption of alcohol and medicine, workers are often exposed to the combined action of occupational chemicals, alcohol, and medicine. Because the mechanism of solvent medicine alcohol interaction is usually not clear, difficulty may occur in interpreting the results of an epidemiological study involving the interaction. ${ }^{34}$

To partially solve this problem, a study design that distinguishes several mutually exclusive categories of potentially hazardous exposure to obtain a reference category may limit the possible confounders. ${ }^{1}$ Besides, one should take a falsification attitude and consider alternative explanations for the abnormal liver function, such as that caused by viral hepatitis, alcohol, or medicines. ${ }^{5}$ Many investigators have reported that the spray painting operation and paint manufacturing industry usually do not produce damage to the liver ${ }^{6-8}$ As the exhaust ventilation is generally not well designed, or installed, in Taiwan, however, we are still concerned that paint manufacturers and sprayers might be suffering from health hazards in the workplace. The purpose of this study was to determine biochemical alterations in liver function among paint manufacturers and sprayers 
and their association with exposure to the organic solvents used in Taiwan. As the prevalence of hepatitis B carriers is as high as $15-20 \%$ in Taiwan ${ }^{910}$ the opportunity was readily available for us to evaluate the possible interaction between the effects of hepatitis B infection and solvents in this study.

\section{Material and methods}

Taipei city has two factories for paint manufacturing, three factories for video terminal painting, two factories for aircraft painting, and one factory for trailer spray painting. All workers who had been working in these factories for more than one year were studied. Also, 200 car painting factories are found in Taipei city and a random sample of 16 of them were included. In total 180 workers were studied.

All the workers were given a comprehensive physical examination, a questionnaire, a liver function test, and a test for hepatitis B surface antigen (HBsAg). The questionnaire contained questions regarding a detailed personal medical history, an extensive occupational history including previous occupational exposure and duration of employment, consumption of alcohol, and medicines taken in the past two weeks. All the interviews were performed by two standardised interviewers in the workplace. We took a walk through survey for each factory before air sampling. Air concentrations of organic solvents were collected by personal samplers and analysed by gas chromatography. We took two to four samples at each factory. A total of 67 air samples were collected, each representing at least four hours of continuous exposure during a complete workday. During the walk through survey we found that car painters had the most serious exposure when working in a poorly ventilated painting booth; they must spend 30-90 minutes in the painting booth every workday. The fluctuation of solvent exposure for car painters could not be neglected, so nine further air samples were randomly chosen from the 16 car painting factories. All nine air samples were collected from the breathing zone when car painters were actually working in the painting booth.

The workers were exposed to a mixture of solvents and eight different solvents were detected in the air. The average contents of xylene and toluene in these air samples were $46 \%$ and $29 \%$, respectively. The air concentration was expressed as the threshold limit value eight hour time weighted average (TLVTWA) (table 1). Table 2 gives the solvent exposure of car painters with serious exposure in the painting booth. The hygienic effect is adopted as a measure of total solvent exposure and is defined as the sum of the fraction of the TLV that each solvent represents. We divided workers into three groups according to the different exposure patterns and different categories of air concentrations in our analysis. These three groups are defined as:

Exposure index 0: This is the low exposure group, including three video terminal painting ( 35 workers) and two aircraft painting (seven workers) factories. They were exposed to a low concentration of organic solvents; the individual solvents detected in the

Table 1 Detected solvents in the air samples of solvent exposed workers. All figures are expressed as TLV-TWA (No of samples $=67$, sampling period $=$ four hours)

\begin{tabular}{|c|c|c|c|c|}
\hline Solvents & Range (ppm) & Mean (SD) (ppm) & $T L V-T W A(p p m)$ & $\begin{array}{l}\text { No of samples that } \\
\text { exceeded the } T L V-T W A\end{array}$ \\
\hline $\begin{array}{l}\text { Xylene } \\
\text { Toluene } \\
\text { Acetone } \\
\text { Benzene } \\
\text { Methyl isobutyl ketone } \\
\text { Methyl ethyl ketone } \\
\text { Ethyl acetate } \\
\text { Butyl acetate }\end{array}$ & $\begin{array}{l}0-365 \\
0-540 \\
0-124 \\
0-20 \\
0-68 \\
0-70 \\
0-29 \\
0-41\end{array}$ & $\begin{array}{l}30(75) \\
19(72) \\
8(24) \\
2(4) \\
2(10) \\
2(9) \\
1(4) \\
2(7)\end{array}$ & $\begin{array}{r}100 \\
100 \\
750 \\
10 \\
50 \\
200 \\
400 \\
150\end{array}$ & $\begin{array}{l}7 \\
1 \\
0 \\
3 \\
1 \\
0 \\
0 \\
0\end{array}$ \\
\hline
\end{tabular}

$\mathrm{TLV}=$ Threshold limit value recommended by the American Conference of Governmental Industrial Hygienist (ACGIH). ${ }^{11}$

Table 2 Detected solvents in air samples of car painters working in painting booths. Figures are expressed as 15 minute time weighted average (No of samples $=$ nine, sampling period $=15$ minutes)

\begin{tabular}{|c|c|c|c|c|}
\hline Solvents & Range (ppm) & $\operatorname{Mean}(S D)(p p m)$ & $T L V-S T E L \dagger(p p m)$ & $\begin{array}{l}\text { No of samples (\%) that } \\
\text { exceeded the TLV-STEL† }\end{array}$ \\
\hline $\begin{array}{l}\text { Toluene } \\
\text { Xylene } \\
\text { Ethyl acetate } \\
\text { Methyl isobutyl ketone } \\
\text { Benzene } \\
\text { Butyl acetate }\end{array}$ & $\begin{array}{r}12-948 \\
25-511 \\
0-483 \\
8-369 \\
7-138 \\
0-258\end{array}$ & $\begin{array}{l}388(391) \\
231(192) \\
115(165) \\
76(115) \\
53(40) \\
50(81)\end{array}$ & $\begin{array}{l}150 \\
150 \\
400 \ddagger \\
75 \\
25 \\
200\end{array}$ & $\begin{array}{l}5(55) \\
4(44) \\
1(11) \\
2(22) \\
8(88) \\
1(11)\end{array}$ \\
\hline
\end{tabular}

+TLV-STEL recommended by the American Conference of Governmental Industrial Hygienists. "

¡No recommended value of TLV-STEL, $400 \mathrm{ppm}$ is the value of TLV-TWA. 
personal samplers were all below a quarter of the hygienic effect concentrations recommended by the American Conference of Governmental Industrial Hygienists (ACGIH). ${ }^{11}$ The $8 \mathrm{~h}$ TWA hygienic effects of solvents ranged from 0 to 0.38 ; and the median level was $0 \cdot 12$.

Exposure index 1: This is the short term high exposure group, including 80 workers who were selected from 16 car painting factories. They were exposed to a low concentration of organic solvents; the $8 \mathrm{~h}$ TWA hygienic effects of solvents ranged from 0 to $3 \cdot 38$; the median value was $0 \cdot 12$. They spend 30 90 minutes in the poorly ventilated painting booth every workday; the 15 minute TWA hygienic effects of solvents while working in the painting booth ranged from 1.32 to 24.52 ; the median value was 10.40. Because such a high level of exposure is usually limited to less than 90 minutes among car painters, they are defined as the short term high exposure group.

Exposure index 2: This is the high exposure group, including two paint manufacturing (19 workers) and one trailer painting ( 39 workers) factory. Most of them were exposed to xylene and toluene. The air concentrations of xylene and toluene detected in the breathing zone were usually above those recommended by ACGIH. The $8 \mathrm{~h}$ TWA hygienic effects of these solvents ranged from 0.25 to $9 \cdot 83$; the median value was 1.66 .

Evaluation of biochemical alterations in liver function was performed by measuring aspartate aminotransferase (AST), alanine aminotransferase (ALT), $\gamma$-glutamyltransferase (GGT), and alkaline phosphatase (ALP) activities, and serum bile acid (SBA) concentrations. Concentrations of SBA were measured by an enzymatic method (Enzabile, Oslo, Norway). Hepatitis B surface antigen was studied with a commercially available solid phase radioimmunoassay (Austria-II, Abbott Laboratories, Chicago, Ill). A $10 \mathrm{ml}$ venous blood sample was drawn from a cubital vein of each worker in the morning (between 0800 and 1000); all the workers were asked to fast overnight. The blood samples were put in a $4^{\circ} \mathrm{C}$ refrigerator in the workplace and immediately centrifugated to obtain the serum after returning to our laboratory. The serum was kept frozen at $-20^{\circ} \mathrm{C}$ until analysed (within four days).

Having found that the distributions of the activities of liver enzymes and SBA concentration are not Gaussian, the non-parametric Wilcoxon rank sum test was used for group comparison. The prevalences of abnormal liver function tests and SBA concentrations between different groups were analysed by the Mantel extension for the test of trend. ${ }^{12}$ The activities of ALT, AST, GGT, ALP, and SBA were also analysed by multivariate regression analysis.

\section{Results}

A total of 180 workers were investigated, divided into three groups according to the different exposure patterns and different categories of air concentrations. In general, workers with high exposure were older and employed longer compared with the other two groups (table 3 ).

Three workers who had a history of blood transfusion were excluded from the analysis to prevent possible confounding by non-A, non-B hepatitis. Table 4 presents results on the influence of nonoccupational factors (alcohol, medicines, $\mathrm{HBsAg}$ ) on liver function. It showed that workers who had an alcohol consumption of greater than $40 \mathrm{gm}$ a day or took medicine (except vitamins and antacids) in the past two weeks were associated with an increase in GGT activities; but this did not reach statistical significance. Significant increases in AL T activity and in SBA concentration $(p<0.05)$, were noted in HBsAg carriers. The standard deviations of liver function tests were comparatively large (table 4) owing to the inclusion of some workers with clearly pathological levels at the time of the study. After workers were stratified individually by age, duration

Table 3 Eight hour hygienic effect of solvents, age, duration of employment, smoking and alcohol consumption, medicines, and $\mathrm{HBs}$ Ag carriers of workers with different indices of exposure

\begin{tabular}{|c|c|c|c|c|}
\hline & \multicolumn{4}{|c|}{ Index of exposure } \\
\hline & $O($ low $)$ & 1 (short term high) & 2 (high) & $\begin{array}{l}p \text { Value of } \\
A N O V A\end{array}$ \\
\hline $\begin{array}{l}\text { Total no of workers examined } \\
\text { Eight hour TWA hygienic effect of solvents } \\
\text { Range } \\
\text { Median } \\
\text { Age (y; mean (SD)) } \\
\text { Duration of employment (y; mean (SD)) } \\
\text { No of smokers (\%) } \\
\text { No with alcohol consumption exceeding } 40 \mathrm{~g} / \text { day (\%) } \\
\text { No of blood transfusions (\%) } \\
\text { No with medicines in past two weeks (\%) } \\
\text { No of HBsAg carriers }(\%)\end{array}$ & $\begin{array}{l}42 \\
0-0 \cdot 38 \\
0 \cdot 12 \\
30 \cdot 3(7 \cdot 6) \\
5 \cdot 7(7 \cdot 4) \\
20(47 \cdot 6) \\
0 \\
1(2 \cdot 4) \\
1(2 \cdot 4) \\
9(21 \cdot 4)\end{array}$ & $\begin{array}{l}80 \\
0-3 \cdot 38(1 \cdot 3-24 \cdot 5) \dagger \\
0 \cdot 12(10 \cdot 40) \dagger \\
26 \cdot 4(8 \cdot 7) \\
6 \cdot 4(6 \cdot 7) \\
52(65 \cdot 0) \\
4(5 \cdot 0) \\
1(1 \cdot 3) \\
6(7 \cdot 5) \\
19(23 \cdot 8)\end{array}$ & $\begin{array}{l}58 \\
0 \cdot 25-9 \cdot 83 \\
1 \cdot 66 \\
41 \cdot 0(12 \cdot 4) \\
17 \cdot 6(13 \cdot 3) \\
40(70 \cdot 0) \\
3(5 \cdot 1) \\
1(1 \cdot 7) \\
8(13 \cdot 8) \\
10(17 \cdot 2)\end{array}$ & $\begin{array}{l}<0.05 \\
<0.05\end{array}$ \\
\hline
\end{tabular}

†The 15 minute TWA hygienic effect of solvents in painting booth. 
Table 4 Serum activities of liver enzymes ( $A L T, A S T, G G T$ ) and concentrations of SBA among workers stratified by alcohol consumption, medicines, and $\mathrm{HBs} A \mathrm{~g}$

\begin{tabular}{|c|c|c|c|c|}
\hline & $A L T(\mu / 1)$ & $A S T(\mu / l)$ & $G G T(\mu / l)$ & $S B A(\mu \mathrm{mol} / \mathrm{l})$ \\
\hline $\begin{array}{l}\text { Alcohol consumption: } \\
>40 \mathrm{gm} / \text { day }(\mathrm{n}=7) \\
\leqslant 40 \mathrm{gm} / \text { day }(\mathrm{n}=170) \\
\text { p Value }\end{array}$ & $\begin{array}{l}12(13) \\
9(8) \\
\text { NS }\end{array}$ & $\begin{array}{l}18(13) \\
17(15) \\
\text { NS }\end{array}$ & $\begin{array}{l}18(9) \\
14(21) \\
<0.05\end{array}$ & $\begin{array}{l}7(11) \\
5(4) \\
\text { NS }\end{array}$ \\
\hline $\begin{array}{l}\text { Medication: } \\
\text { Yes }(n=15) \\
\text { No }(n=162) \\
\text { p Value }\end{array}$ & $\begin{array}{l}14(14) \\
12(13) \\
\mathrm{NS}\end{array}$ & $\begin{array}{l}18(8) \\
18(13) \\
\text { NS }\end{array}$ & $\begin{array}{l}21(20) \\
13(21) \\
\mathrm{NS}\end{array}$ & $\begin{array}{l}9(15) \\
7(11) \\
\text { NS }\end{array}$ \\
\hline $\begin{array}{l}\text { HBsAg carriers: } \\
\text { Carriers }(n=38) \\
\text { Non-carriers }(n=139) \\
\text { p Value }\end{array}$ & $\begin{array}{l}15(11) \\
11(14) \\
<0.05\end{array}$ & $\begin{array}{l}20(14) \\
17(12) \\
\text { NS }\end{array}$ & $\begin{array}{l}12(8) \\
15(23) \\
\text { NS }\end{array}$ & $\begin{array}{c}10(19) \\
6(7) \\
<0.05\end{array}$ \\
\hline
\end{tabular}

Three workers who had had previous blood transfusion were excluded before analysis.

Results are means (SD); NS = non-significant.

of exposure, consumption of alcohol, $\mathrm{HBsAg}$, and use of medicine, we found that GGT activities increased universally among groups of short term high exposure and high exposure compared with the low exposure group. We applied a multiple linear regression model to take account of possible confounding effects. The results showed that GGT activity was associated with both exposure and consumption of alcohol. This association persisted even if the alcohol indicator was expressed as grams of alcohol (g) consumed per day (table 5). Because the age and the duration of exposure are highly correlated with the severity of exposure (Pearson correlation coefficients $r=0.38$ and 0.40 , respectively), we limited the workers to only those who were less than 30 years of age, and the association still persisted; the age and duration of exposure did not influence GGT activity. The concentrations of SBA and ALP activity were associated with the HBsAg state (table 5).

After excluding those who had had previous blood transfusion (three workers) or whose alcohol con- sumption was greater than $40 \mathrm{~g}$ a day (seven workers), the prevalence rate of abnormal enzyme activity and SBA concentration (more than $10 \mu \mathrm{mol} / \mathrm{l}$ ) were $6.5 \%(11 / 170)$ and $12.4 \%(21 / 170)$. If we consider the frequencies of abnormal enzyme activity and SBA concentration among different indices of exposure, however, no statistically significant trend was found because of the small numbers when stratified by HBsAg carrier state (table 6 ).

\section{Discussion}

No strongly hepatotoxic solvents were detected in this study. The major components of solvents were xylene and to a lesser degree toluene. The median air concentrations of $8 \mathrm{~h}$ TWA hygienic effects of solvents for exposure indices 0,1 , and 2 were $0 \cdot 12$, $0 \cdot 12$ ( 10.40 in painting booth), and 1.66 respectively. These concentrations were similar to those reported by some other investigators of paint industry workers $^{713}$; toluene, however, dominated the solvent mixtures used by car painters in Finland. ${ }^{6}$ The total prevalence rate of abnormal liver function in our

Table 5 Effects of solvent exposure, alcohol consumption, $\mathrm{Hbs} \mathrm{Ag}$, and medicines on serum activities of liver enzymes and concentration of SBA among solvent exposed workers by multiple linear regression analysis. (No of workers $=177$ )

\begin{tabular}{|c|c|c|c|c|c|}
\hline Independent variable & & $\begin{array}{l}\text { Exposure } \\
\text { index }\end{array}$ & $\begin{array}{l}\text { Alcohol } \\
\text { consumption }\end{array}$ & $H B s A g$ & Medication \\
\hline Categorisation & & $\begin{array}{l}0: \text { low exposure } \\
1: \text { short term } \\
\text { high exposure } \\
\text { 2: high exposure }\end{array}$ & $\begin{array}{l}0: \leqslant 20 \mathrm{~g} / \text { day } \\
1:>20 \mathrm{~g} / \text { day } \\
\leqslant 40 \mathrm{~g} / \text { day } \\
2:>40 \mathrm{~g} / \text { day }\end{array}$ & $\begin{array}{l}\text { 0: negative } \\
1: \text { positive }\end{array}$ & $\begin{array}{l}0: \text { no } \\
1: \text { yes }\end{array}$ \\
\hline $\begin{array}{l}\text { Dependent } \\
\text { variable }\end{array}$ & Intercept & bl (SE) & b2 (SE) & b3 (SE) & b4 (SE) \\
\hline $\begin{array}{l}\text { ALT } \\
\text { AST } \\
\text { GGT } \\
\text { ALP† } \\
\text { SBA } \\
\text { GGT (age } \leqslant 30) \\
(n=102)\end{array}$ & $\begin{array}{r}15 \cdot 2 \\
11 \cdot 0 \\
7 \cdot 2 \\
133 \cdot 3 \\
4 \cdot 7 \\
6 \cdot 2\end{array}$ & $\begin{array}{c}-0.28(1.35) \\
1.14(1.31) \\
4.88(2.07)^{\star} \\
6.62(7.42) \\
0.75(1.15) \\
3.60(1.14)^{\star}\end{array}$ & $\begin{array}{c}0.46(2 \cdot 18) \\
2.60(2 \cdot 12) \\
9 \cdot 47(3.36)^{\star} \\
-7.47(11.98) \\
0.28(1.87) \\
5 \cdot 70(2 \cdot 77)^{\star}\end{array}$ & $\begin{array}{c}4.11(2.37) \\
3.40(2.29) \\
-0.81(3.63) \\
29 \cdot 26(12.9)^{\star} \\
4.40(2.02)^{\star} \\
0.79(1.73)\end{array}$ & $\begin{array}{c}2.57(3.55) \\
-9 \cdot 17(3.43) \\
5.00(5.43) \\
-13.26(19 \cdot 11) \\
2.36(3.02) \\
3.81(2.80)\end{array}$ \\
\hline
\end{tabular}

$\star$ The $\mathrm{p}$ value of $t$ statistic for coefficient of regression is $<0.05$.

+Because the record of ALP activity of 19 workers from the first paint manufacturing factory (exposure index $2, n=10$ ) and first car painting factory (exposure index $1, n=9$ ) were lost, only 158 workers were analysed for ALP activity. 
Table 6 No of workers with abnormal liver function (defined as $A L T>35 \mu / l$, or $A S T>35 \mu / l$, or $G G T>60 \mu / l$ ) or raised $S B A$ concentration among different exposure indices stratified by $\mathrm{HBs} A \mathrm{~g}$

\begin{tabular}{|c|c|c|c|c|}
\hline \multirow[b]{2}{*}{ State of $\mathrm{HBs} A g$} & \multicolumn{3}{|c|}{ Index of exposure } & \multirow{2}{*}{$\begin{array}{l}\text { Mantel-extension } \\
\text { for the trend }\end{array}$} \\
\hline & 0 & 1 & 2 & \\
\hline $\begin{array}{l}\text { Conventional liver function test: } \\
\operatorname{HBsAg}(+)(\mathrm{n}=38) \\
\operatorname{HBsAg}(-)(\mathbf{n}=132) \\
\text { Total }(\mathrm{n}=170) \\
\text { Odds ratio }\end{array}$ & $\begin{array}{l}2 / 8 \\
1 / 33 \\
3 / 41 \\
1 \cdot 0\end{array}$ & $\begin{array}{l}0 / 20 \\
3 / 55 \\
3 / 75 \\
0.52\end{array}$ & $\begin{array}{l}2 / 10 \\
3 / 44 \\
5 / 54 \\
1 \cdot 34\end{array}$ & $\begin{array}{l}\text { NS } \\
\text { NS } \\
\text { NS }\end{array}$ \\
\hline $\begin{array}{l}\text { SBA concentration: } \\
\operatorname{HBsAg}(+)(n=38) \\
\operatorname{HBsAg}(-)(n=132) \\
\text { Total }(n=170) \\
\text { Odds ratio }\end{array}$ & $\begin{array}{l}0 / 8 \\
4 / 33 \\
4 / 41 \\
1 \cdot 0\end{array}$ & $\begin{array}{r}5 / 20 \\
7 / 55 \\
12 / 75 \\
1 \cdot 64\end{array}$ & $\begin{array}{l}1 / 10 \\
4 / 44 \\
5 / 54 \\
0.93\end{array}$ & $\begin{array}{l}\text { NS } \\
\text { NS } \\
\text { NS }\end{array}$ \\
\hline
\end{tabular}

Workers who had had previous blood transfusion or intake of alcohol exceeding $40 \mathrm{~g}$ /day were excluded.

study was $6.5 \%$, and no association was found between the frequency of abnormality and exposure.

The serum activities of liver enzymes and concentration of SBA seemed to be influenced by nonoccupational factors (table 4). Some authors argued that measurement of SBA concentration is more sensitive than conventional liver function tests such as ALT, AST, and GGT activities and bilirubin concentraton. ${ }^{1314} \mathrm{We}$ also found that the prevalence rate of abnormal SBA concentration $(12.4 \%)$ was higher than found by the conventional liver function tests $(6.5 \%)$. Serum concentrations of bile acid, however, were not different among our three categories of exposure (table 5). After applying a multivariate model to control for all nonoccupational factors, GGT activity was associated with the severity of exposure to the mixtures of solvents. This association persisted even after we limited the workers to those who were less than 30 years of age (table 5). Because the possible effects of alcohol, HBsAg, medicines, and age on GGT activity were under statistical control, we conclude that increased GGT activity among exposed workers may be due to exposure to the mixture of solvents. We consider that GGT activity is probably more useful as a measure than SBA concentration in workers' health surveillance when they are exposed to a mixture of solvents, especially in countries where use of alcohol is not prevalent and xylene is the major solvent used.

Activity of GGT has been generally regarded as a sensitive test for cholestasis and liver cell damage, it is also susceptible to certain drugs and alcohol. ${ }^{15}$ Our data showed that GGT activities increased independently with both an increased consumption of alcohol and exposure to mixtures of solvents. Although it has been reported that long term exposure to low concentrations of solvents may lead to steatosis, ${ }^{16}$ the magnitude of increase in GGT activities for workers in our series seems to be still at a sub-clinical level. Moreover, we found no trend for change in alkaline phosphatase activity (table 5), so we tentatively concluded that the increase in GGT activity may be a phenomenon of enzyme induction. We recommend that a longitudinal study with a long term follow up should be performed to define more clearly the possible hepatotoxic effect among paint workers. This can be done in combination with several other dynamic and static diagnostic tools for the early recognition of possible hazard caused by exposure to the mixture of solvents.

Are HBsAg carriers more susceptible to exposure to a mixture of organic solvents? As a whole, ALT and SBA activities were significantly higher among HBsAg carriers in our study (table 4). But after being stratified by the index of exposure, the prevalence rate of abnormal liver functions and SBA concentration showed no significant trend among different exposure groups. Although we found an increased SBA concentration among $\mathrm{HBsAg}$ carriers after controlling other factors (table 5) no specific trend with the exposure index occurred. We conclude, therefore, that for a moderate level of exposure to the mixture of non-chlorinated organic solvents (for example a median $8 \mathrm{~h}$ hygienic effect up to $1 \cdot 66$ ), $\mathrm{HBsAg}$ carriers seem not to be more susceptible than workers who do not have $\mathrm{HBsAg}$.

This study was supported by a special grant offered from the Taipei City Government. We are also indebted to Drs Ming-Yang Lai and Pei-Ming Yang for their constructive comments.

Requests for reprints to: Dr Jung-Der Wang, Graduate Institute of Public Health, National Taiwan University, College of Medicine, No 1, Section 1, Jen-Ai Road, Taipei, Taiwan, Republic of China (10018).

1 Axelson O. Solvents and the liver. Eur J Clin Invest 1983;13: 109-11.

2 Greech JL, Johnsson MN. Angiosarcoma of the liver in the manufacture of polyvinyl chloride. J Occup Med 1974;16: $150-1$. 
3 Dossing M. Occupational toxic liver change. J Hepatol 1986;3:131-3.

4 Dossing $M$. Metabolic interaction between organic solvents and other chemicals. In: Riihimaki V, Ulfvarson U, eds. Safety and health aspects of organic solvents. New York: Alan R Liss 1986:97-105.

5 Wang JD. Concepts and methods of epidemiologic research. Taipei: National Taiwan University College of Medicine Academic Press, 1989:9-25. (In Chinese.)

6 Kurppa K, Husman K. Car painters' exposure to a mixture of organic solvents. Serum activities of liver enzymes. Scand $J$ Work Environ Health 1982;8:137-40.

7 Lungberg I, Hakansson $M$. Normal serum activities of liver enzyme in Swedish paint industry workers with heavy exposure to organic solvents. $\mathrm{Br} J$ Ind Med 1985;42:596-600.

8 Kurppa K, Tola S, Hernberg S, et al. Industrial solvents and the liver. Lancet 1983;i: 129.

9 Chen DS, Sung JL. Hepatitis B virus infection and chronic liver disease in Taiwan. Acta Hepatogastroenteral 1978;25:423-30.

10 Sung JL, Chen DS, Lai MY, et al. Epidemiology study on hepatitis B virus infection in Taiwan. Chinese Journal of Gastroenterology 1984;1:1-9.

11 American Conference of Governmental Industrial Hygientists.
Threshold limit values for chemical substances in the work environment adopted by ACGIH. Cincinnati, Ohio: ACGIH Inc, 1988.

12 Mantel N. Chi-square tests with one degree of freedom: extension of Mantel-Haenszel procedure. Journal of the American Statistical Association 1963;58:690-700.

13 Franco G, Fonte R, Tempini G, Candura F. Serum bile acid concentrations as a liver function test in workers occupationally exposed to organic solvents. Int Arch Occup Environ Health 1986;58:157-64.

14 Edling C, Tagesson C. Raised serum bile acid concentrations after occupational exposure to styrene: a possible sign of hepatotoxicity? Br J Ind Med 1984;41:257-9.

15 Anonymous. Serum bile acid in hepatobiliary disease. Lancet 1982;ii:137-40.

16 Sotaniemi EA, Sutinen S, Arranto AJ, et al. Liver injury in subjects occupationally exposed to chemicals in low dose. Acta Med Scand 1982;212:2007-215.

17 Dossing M, Arlien-Soborg P, Petersen LM, et al. Liver damage associated with occupational exposure to organic solvents in house painters. Eur J Clin Invest 1983;13:151-7.

Accepted 28 January 1991

\section{Correspondence and editorials}

The British Journal of Industrial Medicine welcomes correspondence relating to any of the material appearing in the journal. Results from preliminary or small scale studies may also be published in the correspondence column if this seems appropriate. Letters should be not more than 500 words in length and contain a minimum of references. Table and figures should be kept to an absolute minimum. Letters are accepted on the understanding that they may be subject to editorial revision and shortening.

The journal now also publishes editorials which are normally specially commissioned. The Editor welcomes suggestions regarding suitable topics; those wishing to submit an editorial, however, should do so only after discussion with the Editor. 